\title{
АВТОРСЬКІ ІНТЕРПРЕТАЦІЇ ОБРАЗУ ПУБЛІЯ ОВІДІЯ НАЗОНА В ПОЛЬСЬКІЙ, АВСТРІЙСЬКІЙ ТА УКРАЇНСЬКІЙ ЛІТЕРАТУРАХ ДРУГОї ПОЛОВИНИ ХХ СТОЛІТТЯ
}

\author{
ІВАН ДАВИДЕНКО \\ Бердянський державний педагогічний університет, Бердянськ - Україна \\ AUTORSKIE INTERPRETACJE OBRAZU PUBLIUSZA OVIDIUSA NAZONA \\ W POLSKIEJ, AUSTRIACKIEJ I UKRAIŃSKIEJ LITERATURZE \\ DRUGIEJ POŁOWY XX WIEKU \\ IWAN DAWYDENKO \\ Państwowy Uniwersytet Pedagogiczny w Berdiańsku, Berdiańsk - Ukraina \\ STRESZCZENIE. Artykuł został poświęcony fenomenowi Publiusza Ovidiusa Nazona, a także \\ jego transformacji z postaci historycznej w obraz literacki. W ujęciu komparatystycznym przeana- \\ lizowane zostały interpretacje biografii artysty w polskiej, austriackiej oraz ukraińskiej literaturze \\ drugiej połowy XX wieku.
}

\section{AUTHORS' INTERPRETATIONS OF PUBLIUS OVIDIUS NASON'S IMAGE IN POLISH, AUSTRIAN AND UKRAINIAN LITERATURE OF THE SECOND HALF OF THE $20^{\text {th }}$ CENTURY}

\section{IVAN DAVYDENKO}

Berdyansk State Pedagogical University, Berdyansk - Ukraine

\begin{abstract}
The article deals with the problem of Ovidius phenomenon in the context of general principles of the interpretation theory. The understanding of the artist's fate in Polish, Austrian and Ukrainian literature of the second half of the $20^{\text {th }}$ century has been investigated. The work also exposes the peculiarity of the ancient Roman writer's transformation from a historical personality into a literary image.
\end{abstract}

еред найталановитіших представників давньоримського письменства чільне місце посідає Публій Овідій Назон (43 р. до н.е. $-17-18$ р. н.е.).

Не лише творчий спадок, а й непересічна доля антика стали причиною посиленої уваги до його постаті. Конфлікт із офіційним режимом і, як наслідок, примусове вигнання у найвіддаленіший куток Римської імперії зробили 3 письменника символ жертви владного молоху. Поет-вигнанець протягом тривалого часу перетворювався з історичної постаті на літературний образ. 
Процес трансформації завершився лише у XX ст., коли тисячі вільномислячих митців стали жертвами насильницьких режимів Іспанії, Італії, Румунії, Німеччини та Радянського Союзу. Саме в часи нехтування свободою творчості, заідеологізованості мистецтва 3 новою силою актуалізувалося вивчення особистості Публія Овідія Назона. Загадкові сторінки біографії, пов'язані з релегацією антика, дали потужний імпульс до художнього моделювання. Особливою концептуальною витриманістю, оригінальністю та подібністю на формальнозмістовому рівні вирізняються романи Овідій Назон - noem (Nazo poeta, 1969) Я. Бохенського, Останній світ (Die letzte Welt, 1988) К. Рансмайра, Скандал в імператорському сімействі (1988) В. Чемериса, а також повість Літній птах на зимовому березі ${ }^{1}$ (1989) Ю. Мушкетика. До сих пір порівняльний аналіз образу Публія Овідія Назона в цих творах не був предметом літературознавчих студій. На сьогодні окремі положення означеної проблеми висвітлено у працях А. Демченко ${ }^{2}$, Л. Скорини ${ }^{3}$ та М. Ільницького ${ }^{4}$, однак вони пропонують лише внутрішньо-типологічне ії розуміння. Тому актуальність нашого дослідження, з огляду на ступінь розробленості зазначеного питання, очевидна.

Мета роботи - дослідити семантичні горизонти образу давньоримського поета в романах Овідій Назон - поет Я. Бохенського, Останній світ К. Рансмайра, Скандал в імператорському сімействі В. Чемериса, а також повісті Літній птах на зимовому березі Ю. Мушкетика. Досягнення мети передбачає розв'язання комплексу завдань, головні з яких: висвітлити поліфонію візій постаті Публія Овідія Назона на прикладі аналізованих художніх текстів; виявити національні домінанти значеннєвих змін образу античного митця.

Дослідження постаті Публія Овідія Назона (далі Овідія), особливостей його „олітературнення” ускладнюється за рахунок відсутності конкретних довідок про життя давньоримського письменника: короткі факти, а в більшості багатозначні натяки - єдине джерело для істориків, літературознавців та письменників. Тому дослідження візій давньоримського митця в текстах сучасної овідіани - це пошук ефемерної тіні, без претензій на вичерпність тлумачення, оскільки наше завдання зводиться фактично до „інтерпретації інтерпретованого", тобто висвітлення закономірностей функціонування образу в авторській уяві та практичної його реалізації в творі.

${ }^{1}$ Вперше повість була надрукована під назвою Літній лебідь на зимовому березі. Див.: Ю. М у ш к е т и к, Літній лебідь на зимовому березі, [в:] „Вітчизна” 1989, № 1, c. $16-68$.

${ }^{2}$ А. Д е м ч е н к о, Особенности историзма повести Ю. Мушкетика „Літній птах на зимовому березі”, [в:] Проблемы художественного историзма, ч. II, Херсон 1990, с. 92-94.

${ }^{3}$ Л. С к о р и н а, Інтерпретаиія образів Овідія та Октавіана Августа у повісті Ю. Мушкетика „Літній птах на зимовому березі” та романі В. Чемериса „Скандал в імператорському сімействі”, [в:] О. Стишов (відп. ред.), Мова культура й освіта в сучасному світі, Київ 2008, с. 90-94.

${ }^{4}$ М. І л ь н и ц ь к и й, Український топос Овідієвих метаморфоз, [в:] „Літературна компаративістика", Київ 2011, вип. IV, ч. I, с. 130-139. 
Так, з-поміж інших авторів, Я. Бохенського вирізняє особлива заглибленість в автентичний текст. На відміну від К. Рансмайра, який міфологізував Овідія, В. Чемериса, який зробив з нього апологета кохання, Ю. Мушкетика, який увів класика в діалог культур, польський письменник зосередився на скрупульозному відтворенні його життя, приділивши левову частку нарації пошуку причин таємничої релегації митця.

Рецепція Овідія в тексті польського письменника позначена прагненням максимально точно реконструювати не тільки його життя, а й дух часу. В концепції Я. Бохенського притаманна 60-им легкість і безтурботність виходить за межі XX ст., гармонійно проектуючись на „Золотий вік” імператора Октавіана Августа (63 р. до н.е. - 14 р. н.е.). Вигадливий конферансьє, яким постає автор, навіює динамічний і водночас простий ритм „відлиги”, що супроводжує програму вистави під назвою Овідій Назон - поет. Майстерно заховавши за лаштунками модних читацьких віянь овідієзнавчу розвідку, Я. Бохенський, таким чином, намагається разом із широкою аудиторією реципієнтів розібратися в заплутаних хитросплетіннях поетичної фантазії давньоримського письменника, якого ототожнив у романі 3 „жонглером-ілюзіоністом” або „фокусником". Ходіння по ретроспективних лабіринтах поетичної свідомості супроводжуються постійними застереженнями автора-конферансьє не піддаватися на численні манівці Овідія, адже „[...] він раз у раз помилятиметься, приховуватиме дійсні факти й підсовуватиме вигадані, збиватиме з пантелику авдиторію, заводитиме іiї на фальшивий слід і кпитиме 3 неі”, сміливо відкинувши суто літературні форми, перетворив роман на виставу 3 елементами детективу, де слідчий - не тільки читач, а й сам автор. Своїм „надзавданням” він зробив якнайглибше осягнення першоджерел і побудову на цій основі давньоримської реальності. Проте мистецтво реконструкції Я. Бохенського не обмежується зануренням у творчий мікрокосм Овідія, прозаїк пішов далі, домисливши вірогідні містки між фактами і тим самим поєднавши окремі картини в суцільне плетиво життя майстра. Письменник не ставив за мету нав'язати читачам своє бачення розвитку подій, він лише запропонував один з безлічі можливих варіантів його розгортання. Такі демократичні інтенції рефлексувалися навіть у формальній організації роману: щоб уникнути непорозумінь, автор взяв у дужки „[ ]” епізоди, імовірність яких непевна. Обмеженість тієї чи іншої інтерпретації образу давньоримського поета наратор пояснює тим, що

тільки поезія Овідія, [...], тільки вона становить джерело даних, основу студій, причину помилок у цих студіях, становить зміст концепту, єдину дійсність та ії̈ заперечення, єдиний факт і заперечення факту. Вона становить замкнене коло, в якому ми кружляємо ${ }^{6}$.

${ }^{5}$ Я. Б о х е н с ь к и й, Овідій Назон - поет, перекл. 3 польської Р. Доценка, Львів 2011, c. 14.

${ }^{6}$ Там само, с. 44. 
Відповідно до цього роман Овідій Назон - поет Я. Бохенського - це яскрава спроба зібрати в єдине ціле всю гаму почуттів та думок, навіяних творчістю класика; можливість доторкнутися до чистого мистецтва, позбавленого офіціозу й апологетики діючих режимів, і разом з тим досвід трагічного відкриття гострого непорозуміння між владою та митцем.

Антитоталітарні мотиви, здебільшого приглушені польським автором, звучать на повну силу в романі Останній світ К. Рансмайра. Визнаний однією 3 вершин постмодерністської літератури, твір австрійського письменника репрезентує історіософське осмислення протистояння між творчою особистістю (Овідій) та носієм панівної ідеології (Октавіан Август).

Будучи яскравим прикладом німецькомовного роману про митця (Künstlerroman), Останній світ К. Рансмайра вирізняється 3-поміж інших відсутністю в тексті творчої особистості як такої. І хоча присутність Овідія як деміурга, за чиїм сценарієм будується сюжет, відчувається на кожній сторінці, автор обмежує уявлення про нього непрямими вказівками у вигляді спогадів і коротких характеристик інших персонажів. Такий спосіб зображення перетворив відомого антика на загадку, розгадати яку сучасний письменник доручив Котті. Товариш і шанувальник Овідієвого таланту насправді в міфологізованому наративі К. Рансмайра постає звичайним політутікачем, одним із багатьох бажаючих „уникнути утисків апарату влади, тотального нагляду, лісу прапорів та торочіння патріотичних гасел" митця, позбавлений традиційно приписуваної йому фізичної слабкості та розпещеності. Замість „жінчиного пахолка” (вислів Я. Бохенського) в Останньому cвimi зображений чоловік з міцним характером, непохитною волею й чіткою суспільною позицією. Рансмайрівський Овідій не приймає корисливий спосіб думання, нав'язаний імператорським псевдодобробутом. Більше того, він пише скандальну комедію Midac, де гостро висміює всіх тих, хто марить грошима.

Навіть побіжний огляд учинків Овідія дає всі підстави говорити про альтернативну історію, запропоновану реципієнтам австрійським літератором. Неприйняття автором будь-яких форм тоталітаризму неочікувано вилилося в бажання перетворити витонченого поета на справжнього опального митця, тому й не дивно, що Овідій-дисидент виявився набагато ближчий естетиці Останнього світу, ніж його вишукано-легковажний еквівалент 3 роману Я. Бохенського. Зображуючи внутрішньосистемний антагонізм, який фактично зводиться до неможливості співіснування в одній державі ідеологічно правильного й вільного мистецтва, К. Рансмайр доходить парадоксальних висновків про те, що історія нічому не вчить людство, а вся наша цивілізованість - лише штучне прикриття споконвічного варварства й жорстокості.

Бажанням дослідити глибинні причини конфлікту між Октавіаном Августом та Овідієм позначений також роман Скандал в імператорському сімей-

${ }^{7}$ К. Р а н с м а й р, Останній світ, перекл. $з$ нім. О. Логвиненка, Київ 1994, с. 176. 
cmвi В. Чемериса. Хоча твір вийшов у світ того ж року, що і Останній світ К. Рансмайра, він не відзначається ані модерною поетикою, тим більше - постмодерними шуканнями. Скандал в імператорському сімействі - класичний зразок українського історичного роману, позбавлений модної сьогодні витіюватості та надуманості. Розповідь автора звучить настільки переконливо, що всі перипетії сюжету, навіть ті, що не мають фактичного підтвердження, здаються реальними і єдиноможливими в тих умовах. Залучення ж широкої галереї історичних постатей, опису давньоримських звичаїв і традицій в сукупності з вичерпною топографією перетворили книгу автора на справжній підручник з історії Давнього Риму, що охоплює один з найцікавіших і водночас найсуперечливіших періодів могутньої держави.

Прозаїк простежує становлення Овідія як обдарованого митця на фоні безкомпромісної боротьби за владу. Його небажання стати придворним поетом викликано абсолютно відмінним світорозумінням, яке не приймало жодних проявів штучності та фальші. Якщо дволикість для Октавіана Августа стала ідеалом і суспільної, і політичної поведінки, то для Овідія вона припустима лише у творчості, а не в реальному житті. Водночас слід додати, що всі письменники-овідієзнавці поділяються на тих, які вважають, що все зображене в елегіях Овідій пережив особисто, і тих, які дотримуються позиції, що більшість 3 написаного - лише елегантна гра фантазії славетного антика. До числа останніх належить і В. Чемерис. На його думку, специфічна амбівалентність Овідія - одна з рис його надзвичайної обдарованості, яка полягає у вмінні перевтілюватися в Іншого:

[...] Овідій-поет і Овідій-людина - то зовсім різні особи, які не треба ототожнювати. Що всі любовні пригоди, про які він пише в елегіях, - то всього лише плід його уяви, творчість, вигадка, фантазія. I навіть його знаменита коханка Корінна, про яку й досі доскіпуються цікаві, - насправді творча уява поета і ніколи не існувала в реальному світі $^{8}$.

Геній же поета-вигнанця автор пояснив тим, що сульмонець першим оспівав справжнє кохання як благородне почуття і до того ж не злякався в своїх елегіях узяти під егіду слабку стать:

Овідій у жінці вбачав перш за все душу. Таємничу, багату, загадкову, здатну на велике почуття і вірність. Бо справжня любов - це не миттєве задоволення, не втіха, це, перш за все, вірність і дружба на все життя 9 .

Серед текстів овідіани Скандал в імператорському сімействі вирізняється докладною розробкою численних зв’язувальних деталей і нюансів. 3 цієї ж причини репрезентована біографічна мозаїка перетворилася на повноцінну картину життя славетного антика, в якій ярко виражені й алюзії до специ-

\footnotetext{
${ }^{8}$ В. Ч е м е р и с, Скандал в імператорському сімействі, Київ 1988, с. 264.

${ }^{9}$ Там само, с. 271.
} 
фічно української дійсності минулих століть, як-то: батьківські повчання, сімейні перекази-побрехеньки, практики повсякдення тощо.

Незалежно від інших авторів, Ю. Мушкетик продовжив розбудовувати мотив циклічності. Український письменник не обмежився тільки проблемно-тематичним рівнем, а пішов далі, зробивши повторюваність наскрізним композиційним прийомом повісті Літній птах на зимовому березі. Узагалі осмислення проблем сучасної історії крізь призму минулого - характерна риса творчого методу прозаїка. М. Жулинський так окреслив цю особливість:

Працює душа письменника - шукає істину в собі заради духовного прозріння і морального зцілення людських душ. Шукає у внутрішній полеміці, в пристрасних діалогах, намагаючись явити світові суперечливий драматизм історичних і сучасних подій, явищ і процесів ${ }^{10}$.

Порівняно з іншими творами в повісті Літній птах на зимовому березі образ класика світової літератури позначений глибоким психологізмом. Концептуальною для Ю. Мушкетика, як і для Овідія, стала „естетика страждання” (термін запроваджений українським поетом В. Стусом). Душевні муки античного поета, породжені страхом ганебної смерті на чужині, постійно гіперболізуються в повісті, набираючи усесвітніх масштабів:

Туга огорнула його, туга їдка, неначе ранковий туман, вона не давала зосередитись на якійсь одній думці, одному болю, а ввібрала в себе все: усі страждання, всі втрати - й не тільки свої- усього світу ${ }^{11}$.

Генетично близька українцям тема політичних утисків із залученням у художній світ образу давньоримського митця отримала додаткового смислового навантаження. Ідеться про ідейний стрижень твору, що максимально сконцентрований в епіграфі: „Що було колись, те й буде знов, що діялося, те й діятиметься, і немає нічого нового під сонцем" ${ }^{\prime 2}$. Слова 3 книги Екклезіаста опосередковано задають загальну тональність повісті, програмуючи на сприймання подій, що в ході історії вже відбувалися. Катастрофізм життя репресованої української інтелігенції в образі Поета постає сучасною проекцією не менш трагічного перебування Овідія в примусовому вигнанні. У цьому зв'язку доречно згадати міркування Т. Іглтона про те, що „теперішнє завжди розуміється лише через минуле, з яким воно створює живу єдність [...]",

\footnotetext{
${ }^{10}$ М. Ж у л и н с ь к и й, Юрій Мушкетик. I виводив він душу з пітьли, [в:] його ж, Украӥнська література: твориі і твори, Київ 2011, с. 896.

${ }^{11}$ Ю. М у ш к е т и к, Літній птах на зимовому березі, [в:] його ж, Смерть Сократа: повісті, оповідання, Харків 2008, с. 240.

12 Там само, с. 235.

${ }^{13}$ Т. И г л т о н, Феноменология, герменевтика, реиептивная теория, [в:] его же, Теория литературы: введение, пер. с англ. Е. Бучкиной, под ред. М. Маяцкого и Д. Субботина, Москва 2010, с. 99.
} 
увівши в художній світ повісті образ славетного антика, переконливо довів, що час не має влади над загальними принципами державного устрою, а надійний механізм всеохоплюючого контролю $є$ невід'ємною частиною будь-якої імперії: чи то давньоримської, чи то радянської.

Отже, розмаїття бачень образу Овідія в європейській літературі другої половини XX ст. викликано бажанням письменників, відкриваючи читачам невідомі сторінки біографії античного поета, зробити з нього носія нових світоглядних та онтологічних принципів і тим самим осучаснити його.

У романі Овідій Назон - поет Я. Бохенського творчість головного героя постає об'єктом грунтовного вивчення і пошуку істинних причин його вигнання, водночас життєпис митця, реконструйований з Любощів та Скорботних елегій, виконує просвітницьку функцію, ознайомлюючи широке коло читачів 3 життям класика світової літератури.

На противагу польському автору, роман Останній світ К. Рансмайра позбавлений підкресленої правдоподібності зображуваного і радше є герметичною системою з багатьма змінними, ніж простором для однозначних оцінок. Зібране з уламків деформованого тексту життя поета-вигнанця під пером австрійського письменника перетворилося на символ, в якому Овідій - уособлення справжнього незаангажованого мистецтва, що не тільки наслідує природу, а й, досягаючи вершин, розчиняється в ній.

Не зважаючи на традиційну поетику, не менш вартісною видається інтерпретація образу Овідія в романі Скандал в імператорському сімействі В. Чемериса. Разом з автором читач має можливість пережити події двотисячолітньої давності, в яких славетний поет, відсторонений від політики, за примхою долі став іграшкою в руках підступного диктатора.

У порівнянні з романами, у повісті Літній птах на зимовому березі Ю. Мушкетика образ давньоримського класика емоційно забарвленіший та глибший за змістовим наповненням. Його полісемантична матриця включає значення: історичної паралелі, в якій вгадуються долі всіх репресованих митців; першого прикладу творчої особистості-жертви політичних ігор, життя якої знищується в невблаганних жорнах владного механізму; беззаперечної істини: вільне мистецтво в тоталітарній державі - міф.

Осягнення інтерпретаційних домінант біографії Овідія не вичерпується окресленим колом питань. Достатньо плідним видається аналіз образу антика в контексті традиційних структур, позаяк географія його художніх реінкарнацій надзвичайно широка. 3 цього випливає необхідність чіткого обгрунтування приналежності Овідія до легендарно-міфологічних постатей, що і становить перспективу нашого подальшого дослідження. 